Journal of Teacher Education for Sustainability, vol. 22, no. 1, pp. 6-20, 2020

\title{
Investigating Home Economics Teachers' Food Waste Practices and Attitudes
}

\author{
Anna-Liisa Elorinne, Lasse Eronen, Milja Pollari, \\ Johanna Hokkanen, and Helen Reijonen \\ University of Eastern Finland, Joensuu, Finland \\ Jamie Murphy \\ University of Eastern Finland, Joensuu, Finland \\ University of Western Australia, Perth, Australia
}

\begin{abstract}
Although studies highlight the role of education in sustainable Food Waste (FW) behaviors, few studies examine basic education pedagogies concerning FW. The present research explores Finnish comprehensive schoolteachers' food and FW attitudes, personal FW practices, and FW pedagogy - educational approach, learning environment, classroom actions, and learning materials. Principal Component Analysis and Spearman correlation analyses of data from a convenience-sampled survey examined FW attitude and practice connections. Respondents ( $\mathrm{n}=52)$, mostly females $(85 \%)$ and Home Economics teachers (62\%), reported two main attitudinal components. Wide Range Responsibility (WRR) represented holistic, global, and communal FW perspectives, while Restricted Responsibility $(\mathrm{RR})$ represented individual and hedonistic FW views. WRR together with school related environmental activities correlated significantly with teacher pedagogical practices to enhance pupils' ability to recognize factors influencing their FW practices. As personal attitudes may carry into teachers' pedagogical practices, future research should examine teachers' personal values and their consistency with basic curriculum values.
\end{abstract}

Key words: sustainable food education, basic education, teacher attitudes, pedagogical practices, home economics

\section{Introduction}

Food waste (FW) environmental, economic and social consequences - e.g., greenhouse gas emissions, nutrient loss, inefficient farmland use and decreased food security cost about $€ 2.4$ trillion globally in 2014 (Food and Agriculture Organization of the United Nations, 2014). This staggering sum has spurred countries and scientific committees, among others, to reduce FW across the entire food supply chain (Parizeau et al., 2015; UN 2015; Laaksonen et al., 2018; Heasly et al., 2020). Dietary and educational guidelines that stress sustainable food education (SFE) are a critical component in this food supply chain (Mason \& Lang, 2017). Consumers and households are central 
actors in FW reduction, for example, consumers in high-income countries waste up to a third of what they buy (Gustavsson et al., 2011). Each year Finnish households generate $120-160 \mathrm{~kg}(15-23 \mathrm{~kg} / \mathrm{pp})$ of avoidable FW - plate leftovers, spoilage and over production - valued at approximately $€ 125 / \mathrm{pp}$ and about $70 \mathrm{~kg} \mathrm{CO} 2$ eq/pp (Katajajuuri et al., 2014; Silvennoinen et al., 2014; 2015). Total household FW also includes nonavoidable FW of inedible vegetable and animal parts such as peelings, bones and coffee grounds (Hartikainen et al., 2020).

Building a sustainable future, a Finnish educational goal (Finnish National Agency for Education, 2014), is consistent with UNESCO (2014) guidelines for Education for Sustainable Development (ESD). Educating for sustainable food consumption (SFC) has primarily been part of nutrition education along with concerns for food (food safety, food system sustainability and related concerns), health (chronic and infectious disease, quality of life) and food availability (social structures, policy, systems) (Contento, 2016). Together, these elements form a sustainable food system that 'conserves and renews natural resources, advances social justice and animal welfare, builds community wealth, and fulfils the food and nutrition needs of all eaters now and in the future' (Tagtow \& Harmon, 2009, p. 2). Hence, SFE integrates both health and environmental perspectives.

Finland's basic curricula conceptualizes pupils' food know-how as pupils' food sense (Janhonen, Torkkeli, \& Mäkelä, 2018). Conceptually, food-sense resembles food literacy with increased learner food agency. Students with high food-sense recognize factors that influence their food choices and can critically evaluate their food related knowledge and skills. These students both understand and appreciate cultural, social and everyday meanings related to food. Generally, such students have a holistic view of food systems, and apply food related knowledge in their every-day life (Janhonen, Mäkelä, \& Palojoki, 2016).

In the Finnish basic curricula, food education is mainly in home economics (HE) content and goals. Particularly in HE, pupils learn practical everyday food management activities that help them take responsibility for their health, human relationships, finances and the comfort and safety of their immediate environment (Uitto \& Saloranta, 2012). HE teachers play a central role in teaching sustainable development (Haapala, Biggs, Cederberg, \& Kosonen, 2014) as all young Finns attend HE lessons. HE, an efficient and effective channel to inform and impact present and future consumers, can reach much wider than just the classroom. Children share knowledge from school with their parents and through this reverse consumer socialization, they influence the entire family's purchase, consumption and recycling behavior (e.g., Ekström, 2007; Gentina \& Muratore, 2012).

As FW is an enormous environmental issue, biology and geography subjects also cover FW as part of their focus on sustainable living and natural resource usage (Finnish National Agency for Education, 2014). The basic curriculum further stresses increased cooperation on food education among different subject teachers and other school actors, such as school catering and health care employees, parents and other food-related stakeholders in society (Finnish National Agency for Education, 2014). This cooperation is important, as the food environment becomes increasingly complex, compromising individual and community food choices (Janhonen, Mäkelä, \& Palojoki, 2016; Jallinoja, Jauho, \& Pöyry, 2019).

Although studies highlight the role of education in influencing sustainable FW behavior (Ekström, 2007; Gentina \& Muratore, 2012; Haapala, Biggs, Cederberg, \& 
Kosonen, 2014; Redman \& Redman, 2014), few studies examine pedagogical practices concerning FW (Øvrebø 2015; Gisslevik, Wernesson \& Larsson, 2018). In addition to education, Silvennoinen (2015) calls for attention to new factors such as citizen value orientation and attitudes to household FW.

The interest in teachers' pedagogical FW practices stems from the broader perspective of teachers' orientation to food sustainability, teachers' understanding of FW phenomena, and competence to give SFE. In this context, broader understanding is teachers' holistic approach to FW phenomena. Teachers understand FW as a food security and an environmental issue; they encourage pupils to use systems thinking while considering complex connections among different stakeholders and actors in food and nutrition systems. Teachers also recognize how different sustainability dimensions (ecological, social and cultural, and economical) link to FW phenomena. In this sense, broader understanding of the phenomena gives teachers better possibilities to ESD (Salite, 2015).

The need to research Finnish teachers' sustainability orientation is even more important as recent research shows that Finnish pupils have inadequate knowledge, e.g., the consequences of climate change (Hermans, 2016). Nordic student teachers do not seem to develop any form of system thinking, and Finnish teacher educators do not connect the four dimensions of sustainable development (political, economic, social and ecological dimensions) to their teaching (Hofman-Bergholm, 2018).

Given the increasing importance of FW, the role of education and cooperation across subjects, this exploratory study - part of a large SFE research project regarding school and household FW - examines Finnish home economics, biology and geography teachers' attitudes towards FW and these teachers' personal and pedagogical practices concerning FW education. In this paper, pedagogical practices are teacher-driven components that frame teaching and learning situations. Among these practices are the educational approach - e.g., learning method, classroom actions - and the teachers' role, learning environment and materials. Two key research foci are: 1) Teacher attitudes, personal FW practices and FW pedagogical practices, and 2) Coherence of teacher attitudes with their personal and pedagogical FW practices.

\section{Theoretical Background}

This research draws on two models - Redman's (2013a) pedagogical approach to effecting change in food and waste behaviors and Kaiser and Fuhrers' (2003) knowledge and attitudes factors determining ecological behavior. Professional competence and experience, i.e., knowledge and practice, tend to influence teachers' pedagogical practices. Personal attitudes and beliefs may also effect teaching practices (Håkansson, 2015).

Professionally skilled teachers recognize core student learning and teaching goals such as the need to improve student system and foresighted thinking, encourage student action orientation and engage different stakeholders in the learning process. Skilled teachers also craft diverse educational approaches - e.g., problem solving, real world learning and experiential learning - to address different knowledge domains (Redman, 2013a).

Rather than the quantity of knowledge, student ecological behaviors relate more to the convergence of four knowledge domains - declarative, effectiveness, procedural and social (Kaiser \& Fuhrer, 2003). For example, a survey of 335 K12 teachers found procedural and social knowledge as statistically significant predictors of K12 students' 
sustainable food and sustainable waste behaviors (Redman \& Redman, 2014). Effectiveness significantly predicted sustainable waste behaviors, but declarative knowledge failed to predict both increased sustainable food and sustainable waste behaviors.

In addition to personal characteristics, school cultural activities affect teachers' pedagogical practices. At least one study suggests that Finnish schools differ in their abilities to influence student sustainability-related values, norms and self-efficacy regarding ecological behavior (Uitto et al., 2015). Based on their findings, Uitto et al. (2015) suggest that schools should increase affective and participatory eco-sustainability experiences, which link closely to adolescents' social context. Today about $15 \%$ of Finnish schools belong to the 'Green Flag School Program' (https://vihrealippu.fi/en/), which places additional environmental education in the school and day care curricula.

A practical subject with hands-on meal preparation in most lessons, HE gives teachers myriad opportunities for diverse learning settings (Hokkanen \& Kosonen, 2013). HE teachers can develop students' food sense using versatile educational approaches. Similarly, HE teachers can help students know and recognize factors that affect their food choices, as well as critically evaluate their food management knowledge and skills. HE teachers can also enhance student understanding of food cultural, social, and everyday meanings through relevant food discussions and assignments. By considering the global perspective and enlightening different food systems, teachers also enhance students' system thinking.

Uitto and Saloranta (2017) found significant differences between Finnish subject teachers' in integrating four different SE dimensions - ecological, economic, social, well-being, cultural - in their teaching. HE teachers typically considered two or three dimensions (economic, social, well-being dimensions) in their SE teaching, however, their approach was not holistic. Instead, biology and geography teachers used holistic sustainability approaches and considered three SE dimensions (ecological, social, and well-being dimensions).

Sustainable food education also takes place during school meals. Teachers other than HE teachers, and other staff, have the possibility to educate children on sustainable food. The effectiveness of this pedagogic meal, however, depends on the role-sociable, educative or evasive - that teachers take during school meals (Osowski, Göranzon, \& Fjellström, 2013).

Scholars have studied HE teachers' SFE pedagogical practices, especially in Nordic countries. The main interest has been factors that facilitate or inhibit teaching Sustainable Food Consumption (SFC) (Gisslevik, Wernesson, \& Larsson, 2018; Haapala, Biggs, Cederberg, \& Kosonen, 2014) and HE teachers' knowledge, teaching practices and attitudes in teaching SFC. Concerning Norwegian HE teacher attitudes towards sustainability, half of the teachers indidicated a personal interest in sustainability and wanted to practice sustainability in the kitchen (Øvrebø, 2015). Two-thirds of the teachers noted sustainable actions in the classroom due to curriculum requirements, rather than a desire to priorize teaching sustainability ( $\varnothing \mathrm{v} r \mathrm{reb} \varnothing, 2015)$. The study concluded that teachers' ideological thoughts and attitudes were relevant in educating competent and thoughtful consumers. Hofman-Bergholm (2017) further concludes in her review that when teachers learn and realize how their different actions affect the system (enhanced systems thinking) their values, ethics and morals become even more important in developing sustainability.

A meta-analysis of psychosocial determinants of pro environmental behavioral intentions suggests that attitudes, behavioral control and personal moral norm predict pro-environmental behavioral intentions (Bamberg \& Möser, 2007). Knowledge, also 
important, is an indirect determinant of pro-environmental intention. Moral and social norms, guilt and attribution processes seem to mediate knowledge impact. The Finnish basic national curriculum grounds all instruction on basic values such as human rights, equality, democracy and endorsing multiculturalism. The curriculum guides pupils towards a sustainable way of life and the importance of eco-social civilization (Finnish National Agency for Education, 2014).

Research of Finnish textbooks suggests that HE textbooks - more so than health education textbooks - focus on food societal, cultural, economic and environmental meanings (Kuurala \& Rauma, 2008). Yet to the authors' best judgement, Finnish HE teacher attitudes towards FW and SFE are unexplored. To help address this gap, the present study examines Finnish HE teachers' attitudes towards FW and SFE, and how these attidues align with the teachers' personal and pedagogical practices.

\section{Subjects and Methods}

\section{Questionnaire Development}

The data stemmed from a structured web-based survey and convenience sampling. The survey instrument, pilot-tested with ten HE students at a Finnish university, drew on research of teachers' SFE, FW and pedagogical practices (Gisslevik, Wernersson, \& Larsson, 2018; Øvrebø, 2015, Redman, 2013a; Redman 2013b; Osowski, Göranzon, \& Fjellström, 2013; Bamberg \& Möser, 2007; Kaiser \& Fuhrer, 2002) and the authors' sustainability expertise. The survey began with respondent background information such as age, gender, present work and teaching experience. The second part, questions 6-22, explored teacher and school pedagogical practices. The third part, questions 2331 , investigated respondents educational approaches such as learning environments, methods and materials. The questionnaire's last part, 30 attitudinal statements (32-62), concerned food value orientations (social, ecological, economical) and teachers' personal FW management (63-66).

\section{Study Participants}

The invitation to participate in the study was via HE, biology and geography teachers' work emails, professional facebook groups, and the biology and geography teachers' union. Altogether 52 teachers responded to the survey (Table 1). All respondents gave their informed consent by ticking "yes" after reading the ethical procedure for collecting, analyzing and publishing the research data.

\section{Data Analysis}

The data was analyzed using SPSS (Statistical Pacakge for the Social Sciences) version 25.0. To explore teacher attitudes, Principal Component Analysis (PCA) followed by Shapiro-Wilk tests for normality helped focus on two key attitudinal approaches. As the distribution of some questions and statements was highly skewed, the non-parametric Spearman correlation analyses examined connections with teacher attitudes, pedagogy and personal practices. 


\section{Results}

\section{Demographics and Principal Component Analysis}

As Table 1 shows, respondents were mostly females (85\%), almost two of three were HE teachers $(62 \%)$ and almost three of four respondents $(73 \%)$ had a long $(4-15$ years) or very long (>15 years) work history. Table 1 also shows respondent PCA component scores, and standard deviations in parentheses.

Table 1

Respondent Characteristics, PCA Cmponent Means and (SDs) ${ }^{1}$

\begin{tabular}{ccccc}
\hline \multicolumn{1}{l}{ Gender } & $\mathrm{n}$ & $\%$ & $\mathrm{WRR}^{2}$ & $\mathrm{RR}^{3}$ \\
\hline Female & & & & \\
\hline Male & 44 & 84.6 & $4.00(.54)$ & $3.30(.68)$ \\
\hline Age & 8 & 15.4 & $3.10(.99)$ & $3.70(.44)$ \\
\hline $22-26$ & & & & \\
\hline $27-42$ & 8 & 15.4 & $3.88(.53)$ & $3.25(.61)$ \\
\hline $43-53$ & 20 & 38.5 & $3.94(.81)$ & $3.16(.63)$ \\
\hline $54-64$ & 10 & 19.2 & $3.94(.68)$ & $3.40(.79)$ \\
\hline Teaching focus & 14 & 26.9 & $3.77(.69)$ & $3.69(.79)$ \\
\hline Home economics & & & & \\
\hline Geography & 32 & 61.5 & $4.08(.52)$ & $3.43(.68)$ \\
\hline Biology & 2 & 3.8 & $2.0(.00)$ & $3.20(.00)$ \\
\hline Elementary & 6 & 11.5 & $3.67(.52)$ & $3.00(.47)$ \\
\hline Years of teaching experience & 12 & 23.1 & $3.80(.77)$ & $3.37(.74)$ \\
\hline$<1$ & & & & \\
\hline 1-3 & 8 & 15.4 & $3.63(.37)$ & $3.37(.23)$ \\
\hline 4-15 & 6 & 11.5 & $3.90(.58)$ & $2.77(.58)$ \\
\hline$>15$ & 16 & 30.8 & $4.10(.89)$ & $3.15(.68)$ \\
\hline Total & 22 & 42.3 & $3.77(.65)$ & $3.65(.64)$ \\
\hline
\end{tabular}

${ }^{1}$ Response options from $5=$ totally agree to $1=$ totally disagree

${ }^{2}$ Wide Range Responsibility component

${ }^{3}$ Restricted Responsibility component

The best PCA model of teacher FW attitudes, survey questions 32-62, yielded two components of six statements each and Crohnbach's alphas from 0.71 to 0.76 (Table 2). The first component, Wide Range Responsibility (WRR), expressed global and communal perspectives of FW, and considered social, ecological and economical dimensions of FW. The second component, Restricted Responsibility (RR), expressed individual FW meanings - e.g., free will, food taste and food appearance - instead of communal meanings. Shapiro-Wilk test results showed a normally distributed RR component and non-normal WRR component distribution. 
Table 2

Constructing Scales Based on PCA

\begin{tabular}{|c|c|c|}
\hline & Wide-range responsibility (WRR) & Restricted responsibility (RR) \\
\hline Statements $(\mathrm{n})$ & 6 & 6 \\
\hline Respondents (n) & 52 & 52 \\
\hline Cronbach's alpha & 0.76 & 0.71 \\
\hline Mean; SD; Skew; Kurtosis & $(3.88 ; .70 ; .94 ; .84)$ & $(3.36 ; .67 ; .00 ; .17)$ \\
\hline Shapiro-Wilk & $\mathrm{W}(51)=.91 ; \mathrm{p}=.001$ & $\mathrm{~W}(51)=.98, \mathrm{p}=.348$ \\
\hline Statements $\left(\right.$ Mean $\left.^{1}, \mathrm{SD}\right)$ & $\begin{array}{l}\text { 47. Today the selection of grocery } \\
\text { stores is too wide }(3.88,1.02) \\
48 \text {. Food marketing should focus } \\
\text { more on preventing food waste } \\
(4.22,0.76) \\
54 \text {. The environmental problems } \\
\text { the earth is facing could be reduced } \\
\text { by preventing the generation of } \\
\text { food waste }(4.14,0.95) \\
56 . \text { Global food production is frac- } \\
\text { tured and produces too much food } \\
\text { for our needs }(3.52,1.18) \\
43 . \text { I am worried about the increase } \\
\text { in food prices induced by food } \\
\text { waste }(3.75,1.03) \\
59 . \text { I am stressed about the amount } \\
\text { of food waste my household } \\
\text { generates }(3.25,0.95)^{2}\end{array}$ & $\begin{array}{l}\text { 34. Food should taste good, } \\
\text { so you can eat it }(3.44,0.94) \\
35 \text {. Food should look attrac- } \\
\text { tive, so that you can eat it } \\
(3.27,1.12) \\
40 . \text { I have the right to decide } \\
\text { what to do with the food I } \\
\text { buy }(3.58,1.05) \\
41 \text {. I have freedom to decide } \\
\text { what and how much I eat } \\
\text { (4.13, } 0.84) \\
57 . \text { Food waste information } \\
\text { is confusing or unnecessary } \\
(2.37,0.97) \\
46 . \text { Less food should be pro- } \\
\text { duced, so that so much of it } \\
\text { would not go to waste ( } 2.77 \text {, } \\
1.10)\end{array}$ \\
\hline
\end{tabular}

${ }^{1}$ Likert scale with response options from $5=$ totally agree to $1=$ totally disagree

${ }^{2}$ Reversed coded item

\section{Teacher's Personal and Pedagogical FW Practices}

The results in Table 3 show that teachers' personal (statements 63, 64 and 66) and pedagogical FW practices (statements 6,12, 14, and 61) got high scores ( $\mathrm{Md}=4)$, suggesting that they more or less agreed with following these practices. The role of school catering and canteen staff in reducing pupils' FW (statements 13 and 17) also rated high $(\mathrm{Md}=4)$, meaning that respondents agreed more or less that catering staff's practice was to remind pupils on minimizing FW. Instead, other asked actions at school concerning SFE (questions 19, 20 and 21) were less agreed ( $\mathrm{Md}=2$ ). 
Table 3

Teachers' (n=52) Pedagogical, Personal and School FW Practices ${ }^{1}$

\begin{tabular}{lc}
\hline \multicolumn{1}{c}{ Questions ${ }^{2,3}$} & $\mathrm{Md}\left(\mathrm{Q}_{1}, \mathrm{Q}_{2}\right)$ \\
\hline & \\
\hline 6. I have told pupils that the FW phenomenon is a global issue & $5(3,5)$ \\
\hline 7. I give pupils an assignment to track their plate waste & $2(1,4)$ \\
\hline 8. I include FW questions at exams & $2(1,4)$ \\
\hline 9. I discuss with pupils generation of FW in different cooking phases & $4(2,5)$ \\
\hline 10. I notice that plate leftovers decrease as pupils learn about FW & $4(2,75,4)$ \\
\hline 11. I discuss with pupils food shopping and generating FW & $4(3,5)$ \\
\hline 12. I remind pupils about minimizing FW when eating & $5(4,5)$ \\
\hline 14. I try to be a role model and not to waste food & $5(4,5)$ \\
\hline 18. FW as a learning topic is difficult to integrate in my teaching & $1(1,2)$ \\
\hline 27. How often do you give textbook assignments to pupils? & $3(2,4)$ \\
\hline 28a. How often did you use e-learning in teaching SFE last year? & $3(2,4)$ \\
\hline 28e. How often did you use e-learning, such as blog writing in SFE last year? & $3(2,4)$ \\
\hline 61. My activity as a role model affects pupils not to waste food & $4,5(4,5)$ \\
\hline \multicolumn{1}{c}{ Personal Practices } & $5(4,5)$ \\
\hline 63. I check refrigerator contents before going shopping & $4(4,5)$ \\
\hline 64. I use leftovers in cooking & $4(4,5)$ \\
\hline 66. I eat foods beyond their best before date & $4(4,5)$ \\
\hline & $3(3,4)$ \\
\hline 13. Our school canteen reminds pupils not to waste food & $4(3,5)$ \\
\hline 15. Our school participates in the autumn national waste week & $4(3,5)$ \\
\hline 16. HE class participates in the autumn national waste week & $2(1,3)$ \\
\hline 17. Our school catering staff supports SFE and guides pupils to decrease plate \\
waste
\end{tabular}

${ }^{1}$ Expressed as $\mathrm{Md}\left(\mathrm{Q}_{1}, \mathrm{Q}_{2}\right)$

${ }^{2}$ Questions 6-21, and 61, Likert scale with response options from 5 - totally agree to 1 - totally disagree

${ }^{3}$ Questions 27, 28a, 28e, and 63-66, Likert scale with response options from 5 - always to 1 never

\section{Coherence of Teacher Attitudes with their Personal, Pedagogical, and School FW Practices}

The results in Table 4 show 2 -tailed significant correlations between FW attitudinal components (WRR, RR) and teachers' pedagogical and personal FW practices. The WRR attitudinal dimension correlated significantly with 11 pedagogical FW practices, two school FW practices, and one personal practice. The RR attitudinal dimension correlated significantly with four pedagogical practices, and two school FW practices such as the school and catering staff's role in SFE and minimizing pupil FW. 

Johanna Hokkanen, Helen Reijonen, and Jamie Murphy

Table 4

Significant Correlations of FW Attitudinal Components (WRR $\left.R^{1}, R R^{2}\right)$ with Teacher Pedagogical, Teacher Personal and School FW Practices

\begin{tabular}{lcc}
\hline \multicolumn{1}{c}{ Pedagogical Practices } & WRR & RR \\
\hline 7. I give pupils an assignment to track their plate waste & $.50^{* *}$ & $.34^{*}$ \\
\hline 8. I include FW questions at exams & $.43^{* *}$ & $.31^{*}$ \\
\hline 9. I discuss with pupils generation of FW in different cooking phases & $.47^{* *}$ & .27 \\
\hline 10. I notice that plate leftovers decrease as pupils learn about FW & $.50^{* *}$ & .01 \\
\hline 11. I discuss with pupils food shopping and generating FW & $.44^{* *}$ & .22 \\
\hline 12. I remind pupils about minimizing FW when eating & $.50^{* *}$ & $.28^{*}$ \\
\hline 14. I try to be a role model and not to waste food & $.54^{* *}$ & .15 \\
\hline 18. FW as a learning topic is difficult to integrate in my teaching & $-.36^{*}$ & -.11 \\
\hline 27. How often do you give textbook assignments to pupils? & -.17 & $.30^{*}$ \\
\hline 28a. How often did you use e-learning in teaching SFE last year? & $.36^{* *}$ & -.26 \\
\hline 28e. How often did you use e-learning, such as blog writing in SFE last year? & $.38^{* *}$ & -.21 \\
\hline 61. My activity as a role model affects pupils not to waste food & $.62^{* *}$ & -.25 \\
\hline \multicolumn{1}{c}{ Personal Practices } & .07 & .15 \\
\hline 63. I check refrigerator contents before going shopping & .23 & -.21 \\
\hline 64. I use leftovers in cooking & $.38^{*}$ & .07 \\
\hline 66. I eat foods beyond their best before date & $.29^{* *}$ & $.47^{* * *}$ \\
\hline & $.15^{*}$ & $.37^{* *}$ \\
\hline 15. Our school participates in the autumn national waste week & $.64^{* *}$ & .12 \\
\hline 17. Our school catering staff supports SFE and guides pupils to decrease plate \\
waste
\end{tabular}

Sig (2-Tailed) * $\mathrm{p}<.05, * \mathrm{p}<.01$ (Spearman correlation coefficient)

${ }^{1}$ Wide Range Responsibility component

${ }^{2}$ Restricted Responsibility component

WRR and RR attitudinal components correlated differently with using learning materials. WRR correlated positively with the frequency of using e-learning in SFE, while RR correlated positively with giving textbook assignments. Considering personal FW practices, the only significant positive correlation was with WWR and eating foods beyond their best before date. There were no significant correlations between RR and personal FW practices.

The results in Table 5 show how seven school actions correlated significantly with six teacher pedagogical practices. As an example, if the school participated in a sustainable education program such as Green Flag School Program or national waste week this correlated positively with teachers paying attention on FW in their teaching. Assigning an FW tracking project and including FW questions on exams correlated significantly and positively with the most school actions, actions 5 and 4, respectively. 
Table 5

Correlations between School and Teacher FW Reduction Practices
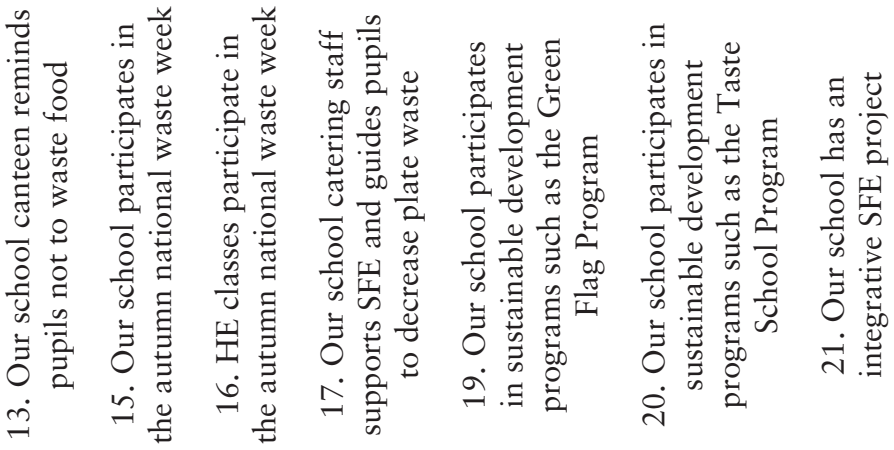

\begin{tabular}{llllllll}
\hline $\begin{array}{l}\text { 6. I have told pupils that } \\
\text { FW is a global issue }\end{array}$ & .05 & $.40 *$ & $.48^{* *}$ & .01 & .22 & .10 & -.04 \\
\hline $\begin{array}{l}\text { 7. I give pupils an assign- } \\
\text { ment to track their plate } \\
\text { waste }\end{array}$ & $.32 *$ & $.58^{* *}$ & $.35^{*}$ & .20 & $.47 *$ & .32 & $.40 * *$ \\
\hline $\begin{array}{l}\text { 8. I include FW questions } \\
\text { at exams }\end{array}$ & $.43 *$ & $.48^{* *}$ & $.40 *$ & .13 & $.31 *$ & -.02 & -.01 \\
\hline $\begin{array}{l}\text { 9. I discuss with pupils } \\
\text { generation of FW in } \\
\text { different cooking phases }\end{array}$ & .10 & .23 & .13 & .07 & $.49 * *$ & .00 & .03 \\
\hline $\begin{array}{l}\text { 10. I notice that plate } \\
\text { leftovers decrease as } \\
\text { pupils learn about FW }\end{array}$ & .06 & $.35 *$ & $.50 * *$ & .09 & $.36 *$ & .09 & .19 \\
$\begin{array}{l}\text { 11. I discuss with pupils } \\
\text { food shopping and } \\
\text { generating FW }\end{array}$ & .03 & $.35 *$ & $.39 *$ & -.04 & .28 & .02 & -.16 \\
\hline
\end{tabular}

Sig $(2-$ Tailed) $* \mathrm{p}<.05, * \mathrm{p}<.01$ (Spearman correlation coefficient)

\section{Discussion}

Generally, teachers who responded the survey were well aware of SFC recommendations, which was seen in both their personal and pedagogical FW practices. This finding was expected since the Finnish basic curricula food education is mainly in HE, and most respondents $(62 \%)$ were HE teachers. Most respondents $(73 \%)$ also had a long (4-15 years) work history, which also was known to affect teacher's professional competence (Tynjälä, 2004).

The research data suggest, however, new observations in comprehensive school teachers' attitudes towards FW, and these attitudes' relationships with teachers' pedagogical and personal FW practices. The PCA analysis (please see Table 2) revealed two attitudinal views of FW responsibility, wide ranging or restricted. The former, WRR, represented a holistic and communal view on FW issue, which emphasized the global awareness of FW as a food security and environmental issue. WRR also expressed connections among global food production, food markets and FW phenomena. In its turn, RR represented individual and hedonistic FW phenomena views such as free will, food 
taste and food appearance. In addition to thematic differences, these two attitudinal components differed across both teachers' personal and pedagogical practices.

The WRR attitudinal component correlated significantly with several teachers' pedagogical practices that can help enhance pupils' ability to recognize factors influencing their food choice and FW, and increase their agency to decrease FW. Among these pedagogical practices were tracking pupils' plate waste and reminding pupils about minimizing FW when eating, discussing generation of FW in different phases of food chain, and the significance and meaning of serving as a role model for not wasting food (Table 4).

Table 1 shows that HE teachers had the highest WRR component score of all teachers, i.e., teachers' pedagogical practices correlated with WRR but not with RR (9, 10,11 and 14) could be more HE teachers in the WRR component. Maybe this result is because HE teachers have better possibilities to implement SFE due to their subject characteristics (curriculum and learning environment) compared to teachers in other disciplines. HE teachers can better note food preparation and food choice effects on FW since cooking is a common practice in HE class (Hokkanen \& Kosonen, 2012). HE teachers can also serve as a role model as well as follow pupils' FW while making and having meals with pupils (Osowski, Göranzon, \& Fjellström, 2013).

Since the convergence of multiple knowledge domains more so than the amount of knowledge determines ecological behavior (Kaiser \& Fuhrer, 2003), converging different knowledge forms probably makes HE teaching more efficient to affect student FW practices compared to teaching in other settings. The WRR component also correlated significantly with teacher practices to use e-learning and one personal FW practice, eating foods beyond their 'best before date'.

Unlike the WRR component correlating significantly with 11 pedagogical practices, the RR component correlated significantly with only four pedagogical practices. Teachers with higher RR also preferred to use textbooks and assignments rather than e-learning in teaching SFE. Demand to decrease FW from the environmental viewpoint is a recent phenomenon and perhaps these teachers found little theoretical FW knowledge in the textbooks. This defect may have affected teaching practices, since Finnish teachers may rely heavily on textbooks when planning their teaching (Venäläinen \& Metsämuuronen, 2015, 87).

In these FW attitudinal dimensions, one can see analogue to peoples' food choice justifications. Where for some people food appearance and taste determine their food choice, for some individuals it is more important to know the origin of food and whether the food is environmentally produced. Based on our results, one can ask is it so that when in the main food choice determinants are food appearance and taste, the probability to throw away food is bigger?

The study results, similar to Øvreb $\varnothing$ (2015), support HE teachers' dichotic attitude towards food sustainability. Teachers with high WRR-attitude scale are professionally skillful and they enhance students' food sense by converging different knowledge forms. They also consider at least two different dimensions of sustainability (ecologic and economic) in their teaching. This observation agrees with Øvrebø (2015) who concluded that ideological thoughts and attitudes were relevant in educating competent and thoughtful consumers. Hofman-Bergholm (2018) also emphasized that should be profesional teachers to consider different dimensions of sustainability in their teaching,

In addition to personal attitudes, school pro-evironmental activities such as participating in the national waste week and belonging to Green Flag School Program correlated significatly with teachers' pedagogical FW practices. 


\section{Limitations and Implications for Future Research}

With 52 respondents and convenience sampling, the results do not generalize and are a rough picture of teacher pedagogical practices and attitudes in reducing FW. Most respondents, however, had a long teaching experience and their gender was similar to Finnish basic education teachers, $77 \%$ female (Kumpulainen, 2017). Respondents were likely to have reported very positively on their FW practices and most likely skewed many variables. Hence, present observations need confirmation by testing with a bigger sample, representative sample, non-Finnish sample and possibly using a seven-point Likert scale.

Future research should also go beyond descriptive and survey research by testing interventions. For example, research could draw upon the Theory of Planned Behavior (Ajzen, 1991) to assess intervention effects on pupils' FW behavior and intentions to reduce FW. As well, what reverse consumer socialization (Ekström, 2007) effects will school interventions have on pupils' parents' and family's purchase, consumption and recycling behaviors?

Since teachers' personal attitudes on food and FW may carry into classroom practices, future research could develop scales for examining the role of teacher attitudes and personal values in developing food sustainability and their connections to values in a curriculum. These findings could help underscore and solidify the importance of school culture concerning pro-environmental activities as well as curricula (basic and local curricula) where SFE should be included in HE and also other school subjects.

\section{Acknowledgements}

Special thanks to Miss Riikka Arasola for collecting the data as part of her Master studies in HE Education.

\section{References}

Bamberg, S., \& Möser, G. (2007). Twenty years after Hines, Hungerford, and Tomera: A new meta-analysis of psycho-social determinants of pro-environmental behaviour. Journal of Environmental Psychology, 27(1), 14-25. https://doi.org/10.1016/ j.jenvp.2006.12.002

Contento, I. R. (2016). Nutrition education: Linking research, theory and practice. Burlington, MA: Jones and Bartlett Learning.

Finnish National Board of Education. (2016). National core curriculum for basic education 2014. Helsinki: Next Print Oy.

Food and Agriculture Organization of the United Nations (2014). Food wastage footprint: Full-cost accounting (final report). Retrieved from http://www.fao.org/3/ai3991e.pdf

Ekström, K. M. (2007). Parental consumer learning or 'keeping up with the children'. Journal of Consumer Behaviour: An International Research Review, 6(4), 203217. https://doi.org/10.1002/cb.215

Gentina, E., \& Muratore, I. (2012). Environmentalism at home: The process of ecological resocialization by teenagers. Journal of Consumer Behaviour, 11(2), 162-169. https://doi.org/10.1002/cb.373 
Gisslevik, E., Wernersson, I., \& Larsson, C. (2018). Home Economics teachers’ perceptions of facilitating and inhibiting factors when teaching sustainable food consumption. Sustainability, 10(5), 1463. https://doi.org/10.3390/su10051463

Gustavsson, J., Cederberg, C., Sonesson, U., Van Otterdijk, R., \& Meybeck, A. (2011). Global food losses and food waste. Retrieved from https://www.madr.ro/docs/indalimentara/risipa_alimentara/presentation_food_waste.pdf

Haapala, I., Biggs, S., Cederberg, R., \& Kosonen, A. L. (2014). Home economics teachers' intentions and engagement in teaching sustainable development. Scandinavian Journal of Educational Research, 58(1), 41-54. https://doi.org/10.1080/ 00313831.2012.696213

Hartikainen, H., Riipi, I., Katajajuuri, J. M., \& Silvennoinen, K. (2020). From measurement to management: Food waste in the Finnish food chain. In Närvänen, E., Mesiranta, N., Mattila, M., \& Heikkinen, A. (Eds.), Food waste management (pp. 415-439). Cham: Palgrave Macmillan. https://doi.org/10.1007/978-3-030-205614_16

Heasly, B., Lindner, J., Iliško, Dz., \& Salìte, I. (2020). From initiatives, to insights, to implementation of the sustainability and securitability agenda for 2030. Discourse and Communication for Sustainable Education, 11(1), 1-4.

Hermans, M. (2016). Från förståelse till agerande: niondeklassares och geografilärares syn på klimatförändringen och undervisningen om klimatförändringen [From understanding to action]. Diss. Åbo Akademi University.

Hofman-Bergholm, M. (2018). Changes in thoughts and actions as requirements for a sustainable future: A review of recent research on the Finnish educational system and sustainable development. Journal of Teacher Education for Sustainability, 20(2), 19-30. https://doi.org/10.2478/jtes-2018-0012

Hokkanen, S., \& Kosonen, A. L. (2013). Do Finnish home economics and health education textbooks promote constructivist learning in nutrition education? International Journal of Consumer Studies, 37(3), 279-285. https://doi.org/10.1111/ijcs.12008

Håkansson, A. (2015). Indoctrination or education? Intention of unqualified teachers to transfer consumption norms in home economics teaching. International Journal of Consumer Studies, 39(6), 682-691. https://doi.org/10.1111/ijcs.12180

Janhonen, K., Torkkeli, K., \& Mäkelä, J. (2018). Informal learning and food sense in home cooking. Appetite, 130, 190-198. https://doi.org/10.1016/j.appet.2018.08.019

Katajajuuri, J. M., Silvennoinen, K., Hartikainen, H., Heikkilä, L., \& Reinikainen, A. (2014). Food waste in the Finnish food chain. Journal of Cleaner Production, 73, 322-329. https://doi.org/10.1016/j.jclepro.2013.12.057

Jallinoja, P., Jauho, M., \& Pöyry, E. (2019). Miten Suomi söi 2008-2016?: Erityisruokavaliot ja niiden taustatekijät [Special diets and associated background factors in Finland in 2008-2016].

Janhonen, K., Mäkelä, J., \& Palojoki, P. (2016). Food education: From normative models to promoting agency. In Sumner, J. (Ed.), Learning, food, and sustainability: Sites for resistance and change (pp. 93-110). Palgrave Macmillan, New York. https:// doi.org/10.1057/978-1-137-53904-5_6

Kaiser, F. G., \& Fuhrer, U. (2003). Ecological behavior's dependency on different forms of knowledge. Applied Psychology, 52(4), 598-613. https://doi.org/10.1111/14640597.00153 
Kumpulainen, T. (2017). Opettajat ja rehtorit suomessa 2016 - Lärarna och rektorerna i Finland 2016 [Teachers and principals in Finland 2016, reports and reviews]. Finnish National Agency for Education, 2.

Kuurala, S., \& Rauma, A. L. (2008). Food and nutrition related values in Finnish health education and home economics secondary school textbooks. Journal of Family and Consumer Sciences, 26(1), 29-41.

Laaksonen, J., Salmenperä, H., Stén, S., Dahlbo, H., Merilehto, K., \& Sahimaa, O. (2018). From recycling to a circular economy. The National Waste Plan 2030. Retrieved from http://urn.fi/URN:ISBN:978-952-xx-Xxxx-x

Mason, P., \& Lang, T. (2017). Sustainable diets: How ecological nutrition can transform consumption and the food system (pp. 147-149, 339). Taylor \& Francis.

$\varnothing v$ rebø, E. M. (2015). How Home Economics teachers in Norwegian lover secondary schools implement sustainability in their teaching. International Journal of Learning, Teaching and Educational Research, 10(2), 72-83.

Osowski, C. P., Göranzon, H., \& Fjellström, C. (2013). Teachers' interaction with children in the school meal situation: The example of pedagogic meals in Sweden. Journal of Nutrition Education and Behavior, 45(5), 420-427. https://doi.org/ 10.1016/j.jneb.2013.02.008

Parizeau, K., von Massow, M., \& Martin, R. (2015). Household-level dynamics of food waste production and related beliefs, attitudes, and behaviours in Guelph, Ontario. Waste Management, 35, 207-217. doi.org/10.1016/j.wasman.2014.09.019

Redman, E. (2013a). Advancing educational pedagogy for sustainability: Developing and implementing programs to transform behaviors. International Journal of Environmental and Science Education, 8(1), 1-34.

Redman, E. (2013b). Opportunities and challenges for integrating sustainability education into k-12 schools: Case study phoenix, AZ. Journal of Teacher Education for Sustainability, 15(2), 5-24.

Redman, E., \& Redman, A. (2014). Transforming sustainable food and waste behaviors by realigning domains of knowledge in our education system. Journal of Cleaner Production, 64, 147-157. https://doi.org/10.1016/j.jclepro.2013.09.016

Salite, I. (2015). Searching for sustainability in teacher education and educational research: Experiences from the Baltic and Black Sea Circle Consortium for educational research. Discourse and Communication for Sustainable Education, 6(1), 21-29. https://doi.org/10.1515/dcse-2015-0002

Silvennoinen, K., Heikkilä, L., Katajajuuri, J. M., \& Reinikainen, A. (2015). Food waste volume and origin: Case studies in the Finnish food service sector. Waste management, 46, 140-145. https://doi.org/10.1016/j.wasman.2015.09.010

Silvennoinen, K., Katajajuuri, J. M., Hartikainen, H., Heikkilä, L., \& Reinikainen, A. (2014). Food waste volume and composition in Finnish households. British Food Journal, 116(6), 1058-1068. https://doi.org/10.1108/BFJ-12-2012-0311

Tagtow, A., \& Harmon, A. 2009. Healthy land, healthy food $\&$ healthy eaters: Dietitians cultivating sustainable food systems. Retrieved from http://www.uwyo.edu/ winwyoming/pubs/healthyland $\% 20$ healthyfood $\% 20$ healthyeaters.pdf

Tynjälä, P. (2004). Asiantuntijuus ja työkulttuurit opettajan ammatissa [Expertise and culture of work in teaching profession]. Kasvatus: Suomen kasvatustieteellinen aikakauskirja [The Finnish Journal of Education], 35, 2. 
UNESCO. (2014). Shaping the future we want. UN Decade of Education for Sustainable Development (2005-2014). Final report, DESD monitoring and evaluation. Retrieved from https://sustainabledevelopment.un.org/content/documents/1682Shaping $\% 20$ the $\% 20$ future $\% 20$ we $\% 20$ want.pdf

Uitto, A., \& Saloranta, S. (2012). Contribution of secondary school subject teachers on the education for sustainable development. In The ESERA 2011 Conference (pp. 127-132). European Science Education Research Association ESERA.

Uitto, A., \& Saloranta, S. (2017). Subject teachers as educators for sustainability: A survey study. Education Sciences, 7(1), 8.

Uitto, A., Boeve-de Pauw, J., \& Saloranta, S. (2015). Participatory school experiences as facilitators for adolescents' ecological behavior. Journal of Environmental Psychology, 43, 55-65. https://doi.org/10.1016/j.jenvp.2015.05.007

United Nations. (2015) Transforming our world: The 2030 Agenda for Sustainable Development. A/RES/70/1. Retrieved from https://sustainabledevelopment.un.org/ content/documents/21252030\%20 Agenda \% 20 for $\% 20$ Sustainable $\% 20$ Development \%20web.pdf

Venäläinen, S., \& Metsämuuronen, J. (2015). Arjen tiedot ja taidot hyvinvoinnin perustana: kotitalouden oppimistulokset perusopetuksen päättövaiheessa 2014 [Evaluation report, learning outcomes 2014]. Julkaisut 2015, 5. Helsinki: Kansallinen koulutuksen arviointikeskus. Retrieved from https://karvi.fi/app/uploads/2015/ 03/KARVI_0515.pdf

Correspondence concerning this paper should be addressed to Anna-Liisa Elorinne, Professor, School of Applied Educational Science and Teacher Education, University of Eastern Finland, P.O. BOX 111, FI-8010 Joensuu, Finland. Email: anna-liisa. elorinne@uef.fi 